\title{
Photochemical quantum efficiency of Aspidosperma pyrifolium (Mart) and Poincianella pyramidalis (Tul.) L. P. Queiroz in an area of semiarid tropics (Soledade City, Paraíba, Northeast Brazil)
}

\section{Everaldo Oliveira Costa Júnior ${ }^{1}$, Érica Caldas Silva-Oliveira ${ }^{2}{ }^{*}$, Juliana Christina Machado de Moura ${ }^{3}$ and Thonny Hill Lima Melo ${ }^{3}$}

${ }^{1}$ Universidade Federal da Paraíba, Campus IV. Fábrica de Tecidos Rio Tinto, Rua da Mangueira S/N, Centro, CEP 58297-000, Rio Tinto, PB, Brazil. E-mail: dygoalmeida@gmail.com

${ }^{2}$ Universidade Estadual da Paraíba, Departamento de Biologia, Rua das Baraúnas, 351, Bairro Universitário, CEP 58429-500 Campina Grande, PB, Brazil. *E-mail: erica.caldas71@gmail.com

${ }^{3}$ Undergraduate studant. Curso de Ciências Biológicas. Universidade Estadual da Paraíba, Rua das Baraúnas, 351, Bairro Universitário, CEP 58429-500 Campina Grande, PB, Brazil.

\begin{abstract}
An analysis of biomonitoring quantum efficiency Aspidosperma pyrifolium (Mart.) and Poincianella pyramidalis (Tul.) L. P. Queiroz, was measured between 2012 and 2013 in order to understand possible strategies of survival for species under extreme drought conditions in Soledade City, semiarid region of Paraíba. Three leafs of the middle portion of randomly arranged in three individuals and populations exposed to intense light, a total of nine replicates per population were chosen. The values of quantum efficiency in $P$. pyramidalis recorded an increase in July (0.652), August (0.785) and September (0.667) of 2012, in response to increased local precipitation occurred in June of 2012. Similar response was observed in the A. pyrifolium which showed mean values of 0.745 in August and 0.685 in September of the same year. $P$. pyramidalis showed greater resistance to water stress, with values of quantum efficiency (0.712), in December of 2012, compared to A. pyrifolium (0.353). The plant species exhibit a seasonal response to water deficit experienced to the study period.
\end{abstract}

Keywords: Photosynthesis, seasonality, photochemical change.

\section{Introduction}

The Caatinga is a vegetation formation restricted to the Brazilian territory. This formation occupies 844,453 $\mathrm{km}^{2}$ in the States of Piauí, Ceará, Rio Grande do Norte, Paraíba, Pernambuco, Alagoas, Sergipe, Bahia, and a small part of the north Minas Gerais corresponding to $11 \%$ of the country's area, housing about 27 million of people. Approximately $45 \%$ of the original vegetation has been cleared of scrub and this degradation continues to grow at a rate of $0.33 \%$ for year (MMA, 2011).

Climatic and soil parameters are the most responsible for different aspects of the savanna physiognomy. However, anthropogenic factors are also responsible for degradation in savanna areas such as 
selective logging, introduction of exotic species, extensive cattle ranching, agricultural management and inadequate extraction of the plant and fire (Amorim et al., 2005).

Caatinga species have peculiar physiological characteristics that reflect environmental adaptations. Thus studies that analyze adaptations to stressful conditions may reveal survival strategies of plants in an environment with extreme weather. Thus analysis of the biology of native species has received greater attention, especially from plant physiologists, so that these studies will support databases for future projects in the semiarid tropics (Trovão et al., 2010; Oliveira, 2011).

Measurements of the photochemical quantum efficiency is an important parameter for assessing ecophysiological responses of plants, which may reflect the environmental conditions in which they develop, thereby providing an understanding of the ecology of the species, which has been revealed in studies in the semiarid region (Oliveira, 2011; Trovão et al., 2010; Trovão et al., 2007; Nogueira et al., 1998).

The photosynthetic rate is an important variable for understanding the physiology of plants. The fluorescence emission occurs when excess light energy absorbed by chlorophyll is dissipated, and re-emitted as light. When it lights a predarkened sample after a minimum of fluorescence level $\left(\mathrm{F}_{0}\right)$ is a rapid increase in fluorescence to a maximum $\left(\mathrm{F}_{\mathrm{m}}\right)$. The variable fluorescence $\left(F_{v}\right)$ is calculated by subtracting $\mathrm{F}_{0}$ from $\mathrm{F}_{\mathrm{m}}$ (Araújo et al., 2004). The $F_{v} / F_{m}$ ratio is the most important variable used by the fluorescence technique and is directly related to the photochemical efficiency of photosystem II (PSII). Values of $0.800 \pm 0.50$ correspond to maximum efficiency in the use of energy in the photochemical process and lower values indicate a reduction in photosynthetic efficiency, caused by some factor (Araújo et al., 2004).

Poincianella pyramidalis (Tul.) L. P. Queiroz, belonge to the family Fabaceae, have a wide dispersion in the savana, occupying both the wet floodplains like Semiarid Seridó and also the coastal hinterland of hills and feet, are presented as alternative feed for livestock, as it has with crude protein content (around 14\%) during much of the year, mainly because it is a species well adapted to most soils and climates, and is very tolerant to dried (Barros et al., 1997; Maia, 2004).

$P$. pyramidalis is still used for its timber, forage and ecological potential, besides being used in folk medicine, which has intensified its massive exploitation currently strategies for multiplication, sustainable management and conservation need.

Aspidosperma pyrifolium known in popular nomenclature as "pau pereiro" is a very common plant in the savanna vegetation, dominant forest in semiarid Northeast, the Apocynaceae and according to Santos (2010) with application for naval use family owned, construction and to reforest areas that have been degraded, especially riparian forests.

With the aim of expanding knowledge of the native flora of the semiarid tropics in the State of Paraíba, especially in seasonal dry period, when species are conditioned to water stress situation, we carried out a study of photosynthetic quantum efficiency and Aspidosperma pyrifolium and Poincianella pyramidalis in the Soledade City.

\section{Materials and methods}

The study was conducted in
Soledade City $\left(7^{\circ} 03^{\prime} 25^{\prime} \mathrm{S}\right.$, $36^{\circ} 21^{\prime} 46^{\prime \prime} \mathrm{W}$ ) which is in the middle region of Paraíba arid, Curimataú Westerner small (Figure 1), taken monthly in the period of April of 2012 to June of 2013, to assess the photosynthetic efficiency in a population of $A$. pyrifolium and $P$. pyramidalis. For this region, temperatures range between $20^{\circ} \mathrm{C}$ and $30^{\circ} \mathrm{C}$ with average annual rainfall ranging around $550 \mathrm{~mm}$, concentrated in the months from March to August. The climate of the county, according to the classification of Koopen, is the type Bsh semiarid. The survey area in the county was $10 \mathrm{~m} \times 20 \mathrm{~m}$ $\left(200 \mathrm{~m}^{2}\right)$, located in a rural area.

For the assessment of photosynthetic efficiency we adopted the methodology described in Trovão et al. (2007) picking up three sheets of the middle 


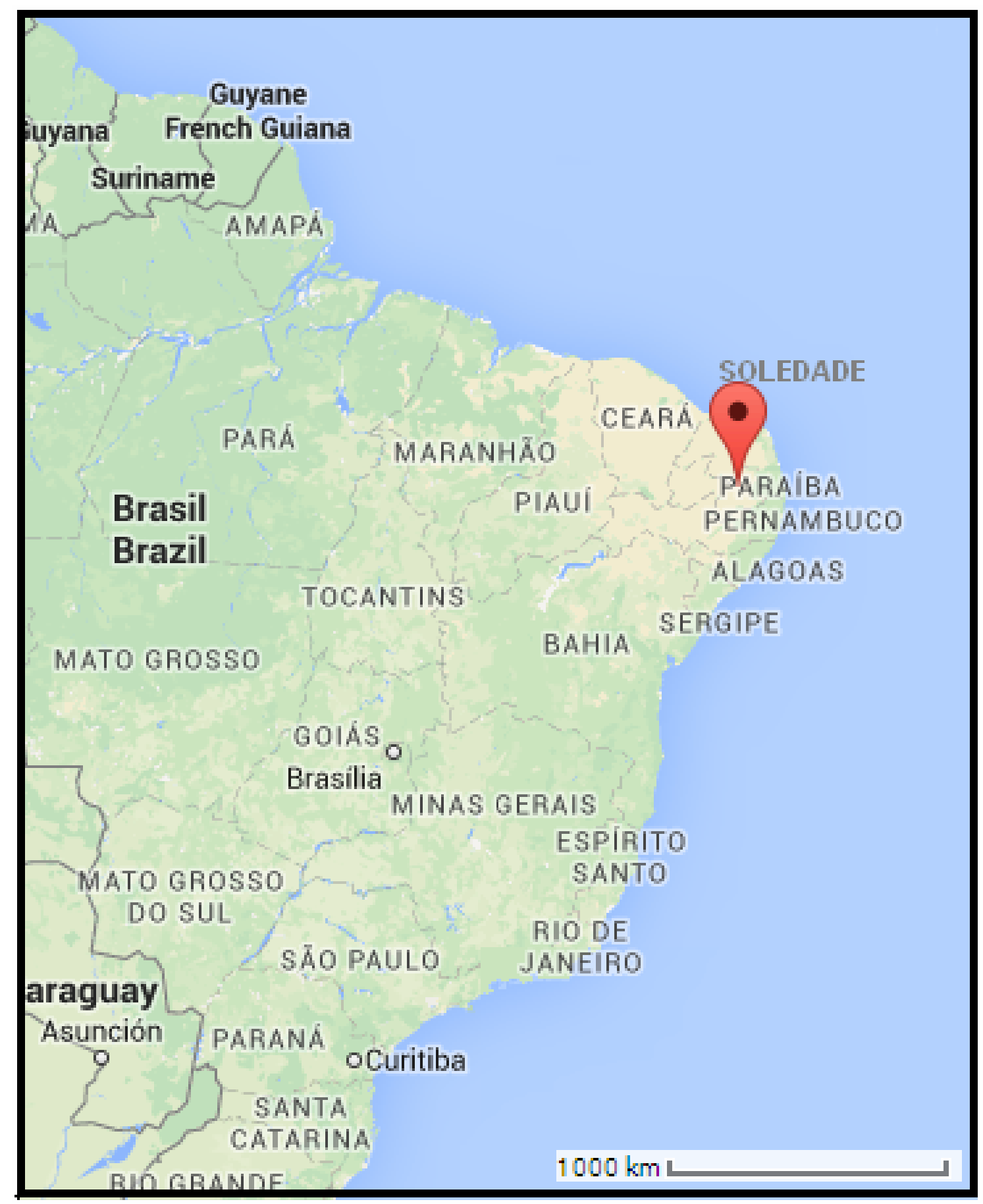

Figure 1. Location map of the Soledade City, State of Paraíba, Brazil. Adapted from Google Maps.

portion of three adult individuals arranged randomly in the population, since fully exposed to light intensity, accounting for a total of nine replicates in each population. During the procedure using always the same leaves throughout the experiment, one leaf was placed clip retaining a portion of the leaf area covered free of luminous intensity after a period of approximately 90 minutes (Kautsky Effect) carried if the measurements of fluorescence emission with outlets carried out in the early morning hours extending to 09:00 am, through a fluorescence detector type PEA (Plant Efficiency Analyser) determining $\mathrm{F}_{0}$ (minimal fluorescence or initial), $F_{v}$ 


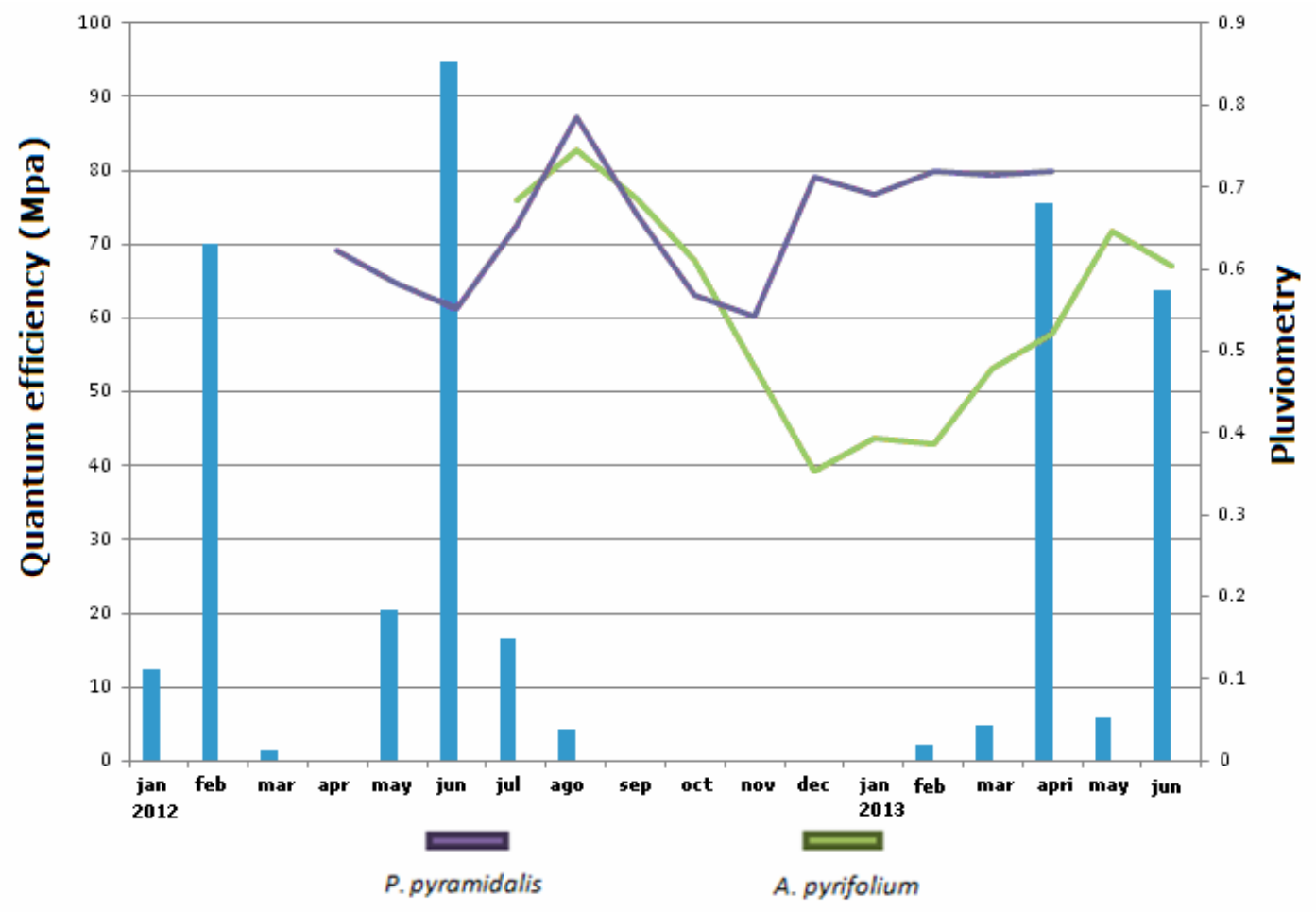

Figure 2. Seasonal variation in the values of quantum efficiency of individuals of $P$. pyramidalis and A. pyrifolium (Soledade City, State of Paraíba, Brazil), from April 2012 to June 2013.

(increase in fluorescence from $\mathrm{F}_{0}$ to $\mathrm{F}_{\mathrm{m}}$ ), $\mathrm{F}_{\mathrm{m}}$ (maximal fluorescence) and the $\mathrm{F}_{\mathrm{v}} / \mathrm{F}_{\mathrm{m}}$ ratio that enables the determination of the quantum yield of photochemical step in photosynthesis.

\section{Results and discussion}

In Figure 2 the average values of the photochemical quantum efficiency of photosystem II and for Poincianella pyramidalis and Aspidosperma pyrifolium are presented throughout the analysis period. The values presented showed that species respond to the effects of drought and reduce the photosynthetic efficiency related to photosystem II.

Importantly, the $P$. pyramidalis even keeping the foliage during the drier periods of the year, yet the species is experiencing throughout the dry season a limitation of photosynthetic activity.

This was observed for the month of June of 2012, with mean values of photosynthetic efficiency were 0.551 reflecting the dry period previously experienced by individuals in the population between the months of March to May.

Chernyad'ev (2005) states that water stress conditions affect the synthesis of pigments chlorophyllian, directly influencing the ratio of chlorophyll $a / b$ however the rates of decrease in chlorophyll $a$ and $b$ various reasons since the chlorophyll $b$ is more likely the destruction caused by water stress.

The ratio of chlorophyll $a / b$ is a parameter for analyzing the water stress in plants, thus changing the value of the parameter $a / b$ observed under conditions of water deficit reflect differences in the characteristics of fluorescence induction conditioning a reduction in the rate of photochemical efficiency as those recorded by $P$. pyramidalis and $A$. pyrifolium during periods of increased drought.

An increase in the values of photosynthetic quantum efficiency between the months of July (0.652), August (0.785) and September (0.667) in individuals of $P$. pyramidalis, possibly in response to the higher amount of water in the soil resulting from high was observed amounts of rainfall for the month of June 2012 (94.6 mm) prior 
to the collection. A similar profile was observed for A.pyrifolium that showed values of quantum efficiency of 0.745 for the month of August and 0.685 for the month of September of 2012.

Values greater than 0.750 indicate a satisfactory condition photosynthetic efficiency of the plant, as seen in August (P. pyramidalis) and around maximum efficiency in photochemical process since values of $0.800 \pm 0.05$ corresponding to the maximum efficiency in energy use in the photochemical process (Torres Neto, 2002; Trovão et al., 2007) have values less than 0.750 indicate stress conditions and thus reduce photosynthetic potential in plant of the according to Maxwell and Johnson (2000), Araújo et al. (2004 ) and San José (1977).

It was registered a decrease in photochemical activity between the months of October and November of 2012 for the species analyzed with 0.568 and 0.542 for P. pyramidalis and 0.611 and 0.482 for A. pyrifolium, respectively. The low photosynthetic activity on the period may be associated with low rainfall the AESA (2012-2013) (Figure 2).

A similar response was observed by Oliveira (2011), in a study conducted in Western Seridó Paraiba with Cnidoscolus quercifolius Pohl showed that seasonality relative to the values of quantum efficiency of photosynthesis in situations of water stress, with record average values of the order of 0.591 during the dry season.

Seasonal variations in the quantum efficiency were also observed by Trovão et al. (2007) in Caatinga species in Cariri between the wet and dry seasons, the species studied Commiphora leptophleoeos Mart. was reported that a greater percentage difference between stations.

According to Nogueira et al. (1998) and Nogueira and Silva (2002) the first line of defense to water deficit is stomatal closure, since the diffusive resistance to water vapor reduces perspiration. The lower values observed for the photosynthetic quantum efficiency between the months of September to November 2012 in individuals of $P$.pyramidalis and A. pyrifolium may be associated with damage to the stomatal apparatus and consequently causing damages photosynthetic capacity of individuals.

Photochemical damage to photosystem II under drought conditions were analyzed by Silva et al. (2010). Studies of the quantum efficiency of PSII performed by Santos et al. (2013) showed that Jatropha curcas L. species revealed a decrease in $\mathrm{F}_{\mathrm{v}} / \mathrm{F}_{\mathrm{m}}$ in semiarid region of Northeastern Brazil during the driest months of the year, with values of quantum efficiency of 0.51 for the hottest hours of the day, these stress conditions, the species also showed an increase in the concentration of proline and soluble amino acids.

Despite a period of approximately six months without rain, surprisingly the photochemical quantum efficiency values again show a rise considerably from December of 2012 with index (0.712) for $P$. pyramidalis species. The months from January to March average present values of quantum efficiency of the order of 0.714 even in extreme water stress. It is observed in the population of $P$. pyramidalis that individuals lose their leaves sharply, however seem to keep an escape mechanism to water stress.

A response to water stress was analyzed by Silva et al. (2004) studying ecophysiological aspects of ten species of the Caatinga in Cariri, related to osmotic adjustment in water deficit conditions. These authors observed that among the analyzed species P.pyramidalis (Caesalpinia pyramidalis) presented a marked accumulation of free proline accumulation and that this may represent a survival mechanism to the stress period due to a better osmotic adjustment induced by this amino acid. Since we observe a marked accumulation of free proline in plants subjected to drought stress.

The accumulation of metabolites may be an important mechanism in the plants for tolerance to water stress conditions. The accumulation of proline acts as a mediator for osmotic adjustment, protecting the integrity of the plasma membrane as a source of carbon and nitrogen and promotes the reduction of reactive oxygen species (Johari-Pireivatlou et al., 2010). 
Water deficit primarily affects the stomatal apparatus causing stomatal closure, however when plants undergo prolonged drought cycles they may develop some resistance to the lack of water, keeping perspiration for longer periods (Lacher, 2004; Silva et al., 2008), as observed in individuals of $P$. pyramidalis which seem to maintain physiological mechanisms of drought escape, even under conditions of water deficit revealing a drought tolerance for the species.

In a study of wheat cultivars Chernyad'ev (2005) observed a rapid increase in the ratio of chlorophyll $a / b$ when subjected to conditions of greater water stress indicating high resistance to water deficit in the plant, which may be associated the increase in the values of quantum efficiency in P. pyramidalis.

The physiological response of A. pyrifolium, whose collections were initiated in July 2012, presents different from that found in $P$. pyramidalis since individuals of $A$. pyrifolium describe a strong decreases in quantum efficiency from September of 2012 to March of 2013 period when rainfall is low including no record of rainfall between the months of September to December of 2012 and January of 2013 (Figure 2). December of 2012 was the lowest value of photosynthetic quantum efficiency of 0.353 . This value indicates a marked decrease in photosynthetic rates with involvement of plant physiology. In this period of more severe water stress plants of A. pyrifolium lost their foliage and only five individuals in the population have remained with leaves. The values of quantum efficiency remained low in February (0.387) and March (0.479) again displaying an increase in quantum efficiency between the months of April (0.522), May (0.647) and June $(0.603)$ probably in response to an increase in rainfall recorded for this period. Still, the values of quantum efficiency are low and show that the species A. pyrifolium shown to be more sensitive to water deficit conditions compared to $P$. pyramidalis.

\section{Conclusions}

Poincianella pyramidalis (Tul.) L. P. Queiroz and Aspidosperma pyrifolium
Mart. respond to the effects of drought reducing their photosynthetic efficiency related to photosystem II as a result of the drought that are submitted. P. pyramidalis looks better resist the effects of drought and even registering an increase in levels of quantum efficiency in very dry periods.

\section{Acknowledgements}

The authors wish to express their thanks to the owners of São José Farm, in the Soledade City, where the data collection for this study occurred.

\section{References}

AESA - Agência Executiva de Gestão das Águas do Estado da Paraíba. Available from: $<$ http://www.aesa.pb.gov.br $>$. Accessed in: Nov. 17, 2012.

Amorim, I. L.; Sampaio, E. V. S. B.; Araújo, E. L. Flora e estrutura arbórea de uma área de Caatinga no Seridó, RN, Brasil. Acta Botânica Brasilica, v. 19, p. 615-623, 2005.

Araújo, R. A.; Siqueira, D. L.; Martinez, C. A.; Fernandes, A. R. Características biométricas, Índice SPDA-502 e emissão de fluorescência em porta enxertos de citros. Revista Ceres, v. 51, p. 189-199, 2004.

Barros, N. N.; Sousa, F. B.; Arruda, F. A. V. Utilização de forrageiras e resíduos agroindustriais por caprinos e ovinos. Sobral: Embrapa-CNPC, 1997.

Chernyad'ev, I. I. Effect of water stress on the photosynthetic apparatus of plants and the protective role of cytokinins: A review. Applied Biochemistry and Microbiology, v. 41, p. 115128, 2005.

Johari-Pireivatlou, M.; Qasimov, N.; Maralian, H. Effect of soil water stress on yield and proline of four wheat lines. African Journal of Biotecnology, v. 9, p. 36-40, 2010.

Larcher, W. Ecofisiologia vegetal. São Carlos: Rima, 2004.

Maia, G. N. Caatinga: Árvores e arbustos e suas utilidades. São Paulo: D\&Z Computação, 2004.

Maxwell, K.; Johnson, G. Chlorophyll fluorescence-a pratical guide. Journal of Experimental Botany, v. 51, p. 659-668, 2000.

MMA - Ministério do Meio Ambiente. Monitoramento do Desmatamento nos Biomas Brasileiros por Satélite: Monitoramento do Bioma Caatinga 2008 2009. Brasília: MMA/IBAMA, 2011. (Acordo 
de Cooperação Técnica MMA/Ibama). Available from: <http://www.mma.gov.br/ estruturas/sbf_chm_rbbio/_arquivos/relatorio_te cnico_caatinga_2008_2009_72.pdf $>$. Accessed in: Apr. 16, 2014.

Nogueira, R. J. M. C.; Melo Filho, P. A.; Santos, R. C. Curso diário do potencial hídrico foliar em cinco espécies da Caatinga. Revista Ecossistema, v. 23, p. 73-77, 1998.

Nogueira, R. J. M. C.; Silva, E. C. Comportamento estomático em plantas jovens de Schinopsis brasiliensis Engl. cultivadas sob estresse hídrico. Iheringia, Série Botânica, v. 57, p. 31-38, 2002.

Oliveira, E. C. S, Caracterização biológica de Cnidoscolus quercifolius Pohl em área de Caatinga do Seridó Ocidental Paraibano. Campina Grande: Universidade Federal de Campina Grande, 2011. (Doctorat Thesis).

San José, J. J. Potencial hídrico e intercâmbio gaseoso de Curatella americana L. en la temporada seca de la sabana de Tractrypogon. Acta Científica Venezoelana, v. 23, p. 373379, 1977.

Santos, C. M.; Veríssimo, V.; Wanderley-Filho, H. C. L.; Ferreira, W. M.; Cavalcante, P. G. S.; Rolim, E. V.; Endres, L. Seasonal variations of photosynthesis, gas exchange, quantum efficiency of Jatropha curcas L. grown in semihumid and semi-arid areas subject to water stress. Industrial Crops and Products, v. 41, p. 204-213, 2013.

Santos, P. B. Contribuição ao estudo químico, bromatológico e atividade biológica de angico, Anadenanthera colubrina (Vell.) Brenan. var. cebil (Gris.) Alts e pereiro, Aspidosperma pyrifolium Mart. Patos: Universidade Federal de Campina Grande, 2010. (Mater Thesis). Available from: <http://www.cstr.ufcg.edu.br/ ppgz/dissertacoes/dissertacao_\%20petrushka_be zerra_santos.pdf $>$. Accessed in: Oct. 22, $201 \overline{2}$.
Silva, E. C.; Nogueira, R. J. M. C.; Azevedo Neto, A. D.; Brito, J. Z.; Cabral, E. L. Aspectos ecofisiológicos de dez espécies em uma área de Caatinga no Município de Cabaceiras, Paraíba, Brasil. Iheringia, Série Botânica, v. 59, p. 201205, 2004.

Silva, M. A. V.; Nogueira, R. J. M. C.; Oliveira, A. F. M.; Santos, V. F. Resposta estomática e produção de matéria seca em plantas jovens de aroeira submetidas a diferentes regimes hídricos. Revista Árvore, v. 32, p. 335-344, 2008.

Silva, E. V.; Ferreira-Silva, S. L.; Fontenele, A. V., Ribeiro, R. V.; Silveira, A. G. Photosynthetic changes and protective mechanims against oxidative damage subjected and combined drought and heat stresses in Jatropha curcas L. plants. Journal of Plant Phyology, v. 167, p. 1157-1164, 2010.

Torres Neto, A.; Campostrini, E.; Oliveira, J. G.; Yamanishi，O. K. Portable chlorophyll meter for the quantification of photosynthetic pigments, nitrogen and the possible use for assessment of the photochemical process in Carica papaya L. Brazilian Journal of Plant Physiology, v. 14, p. 203-210, 2002.

Trovão, D. M. B. M.; Fernandes, P. D., Andrade, L. A., Dantas Neto, J. Variações sazonais de aspectos fisiológicos de espécies da Caatinga. Revista Brasileira de Engenharia Sanitária e Ambiental, v. 11, p. 307-311, 2007. Trovão, D. M. B. M.; Alves, R. R. N.; Dantas Neto, J.; Fernandes, P. D.; Andrade, L. A. Fragments of Caatinga in the Sub-Basin of Rio Bodocongó: A conservation study in the Brazilian Semi-Arid Tropics. In: Degenovine, K. M. (Org.). Semi-arid environments: Agriculture, water supply and vegetation. New York: Nova Sciencie Publishers, 2010.

License information: This is an open-access article distributed under the terms of the Creative Commons Attribution License, which permits unrestricted use, distribution, and reproduction in any medium, provided the original work is properly cited. 